\title{
Prevalence and susceptibility of infection to Myxobolus cerebralis, and genetic differences among populations of Tubifex tubifex
}

\author{
Katherine A. Beauchamp ${ }^{1, *}$, Melanie Gay ${ }^{1}$, Garry O. Kelley ${ }^{1}$, Mansour El-Matbouli², \\ R. Deedee Kathman ${ }^{3}$, R. Barry Nehring ${ }^{4}$, Ronald P. Hedrick ${ }^{1}$ \\ ${ }^{1}$ Department of Medicine and Epidemiology, School of Veterinary Medicine, University of California, Davis, \\ California 95616, USA \\ ${ }^{2}$ Institute of Zoology, Fish Biology and Fish Diseases, Faculty of Veterinary Medicine, University of Munich, \\ Kaulbachstr. 37, 80539 Munich, Germany \\ ${ }^{3}$ Aquatic Resources Center, College Grove, Tennessee 37046, USA \\ ${ }^{4}$ Colorado Division of Wildlife, 2300 Townsend Avenue, Montrose, Colorado 81401, USA
}

\begin{abstract}
The prevalence of infection and susceptibility of the aquatic oligochaete Tubifex tubifex to Myxobolus cerebralis, was examined in 2 studies on the upper Colorado River, Colorado, USA, where whirling disease occurs in wild trout populations. In the first study, the prevalence of infection ranged from 0.4 to $1.5 \%$, as determined by counting the number of $T$. tubifex releasing triactinomyxons of $M$. cerebralis directly following their collection from the field. The susceptibility of those T. tubifex not releasing triactinomyxons was assessed by the number of these oligochaetes releasing triactinomyxons 3 mo following experimental exposures to spores of M. cerebralis. The prevalence of infection following experimental exposures of these T. tubifex ranged from 4.2 to $14.1 \%$. In a second study, all T. tubifex collected at 2 different times directly from the 2 field sites in Colorado were exposed to spores of M. cerebralis. Individual oligochaetes representing those groups of $T$. tubifex releasing and those groups not releasing triactinomyxons at 3 mo were screened with molecular genetic markers. T. tubifex populations found at the 2 study sites consisted of 4 genetically distinct lineages that varied with respect to their susceptibility to experimental exposure to $M$. cerebralis. Lineages I and III contained the most oligochaetes susceptible to $M$. cerebralis and were the most prominent lineages at Windy Gap Reservoir, a site of high infectivity for wild rainbow trout on the upper Colorado River. In contrast, at the Breeze Bridge site which is below Windy Gap Reservoir and where $M$. cerebralis infections are less severe in wild trout, oligochaetes in lineages V and VI that are resistant to $M$. cerebralis were more prominent. These results suggest that certain habitats, such as Windy Gap Reservoir, are conducive to large and more homogenous populations of susceptible $T$. tubifex lineages that may serve as point sources of infection for $M$. cerebralis. Although not a direct objective of this study, there was no evidence of $M$. cerebralis infections among any oligochaetes other than those that would be classified as T. tubifex by standard morphological characteristics.
\end{abstract}

KEY WORDS: Whirling disease $\cdot$ Myxobolus cerebralis $\cdot$ Tubifex tubifex

\section{INTRODUCTION}

The effects of parasites on wild and free-ranging fish populations are poorly understood, in part due to the

*E-mail: kabeauchamp@ucdavis.edu complexity of the interrelating factors that influence host and pathogen relationships when the environment cannot be tightly controlled, as in aquaculture (Hedrick 1998). Parasites such as Myxobolus cerebralis, the causative agent of salmonid whirling disease, have recently been recognized as causes of catastrophic de- 
clines among wild rainbow trout populations in the states of Idaho, Montana, Colorado and Utah, USA (Nehring \& Walker 1996, Vincent 1996, Hedrick et al. 1998). M. cerebralis is the best known of 1300 parasites grouped in the phylum Myxozoa and the first shown to possess a 2 host life cycle including salmonid fish and an aquatic oligochaete, Tubifex tubifex (Markiw \& Wolf 1983, Wolf \& Markiw 1984, Wolf et al. 1986). The parasite has been observed among wild fish in 23 states in the USA, but without the same disastrous effects observed in the intermountain west (Nickum 1999). The differences in the impacts on wild fish between geographic regions is not easily traced to different 'strains' of the parasite, since $18 \mathrm{~S}$ and ITS-1 rDNA sequences were identical for isolates of the parasite from 4 North American sites and 1 German site (Andree et al. 1999). In addition, there was no apparent difference in the virulence for experimentally infected rainbow trout with parasites obtained from high- and low-impact enzootic locations of whirling disease (McDowell et al. unpubl. data). Salmonid species exhibit a range of susceptibility to $M$. cerebralis ranging from resistant to highly susceptible (O'Grodnick 1978, 1979, El-Matbouli et al. 1999a, Hedrick et al. 1999a,b). The mechanisms by which fish resist $M$. cerebralis infections are currently under investigation (Hedrick et al. unpubl. data). While our understanding of the parasite during development in the fish has progressed, much less is known about the parasite in tubificid oligochaetes, the hosts that are now viewed as potentially central to the severity and eventual management of whirling disease in certain wild trout populations.

A group of related aquatic annelids (Oligochaetae, Tubificidae) have been the focus of a number of ecological and systematic studies because of their importance as indicators of aquatic pollution and as alternate hosts to fish parasites (Kent et al. 1994, Day et al. 1995, Brinkhurst 1996). Three families of oligochaetes are known to host myxosporean parasites, but Tubifex tubifex is reported to be the only host for Myxobolus cerebralis (Markiw \& Wolf 1983, Wolf et al. 1986, El-Matbouli \& Hoffman 1989, 1995). Currently, the taxonomy and systematics of oligochaetes depends on morphological characteristics of sexually mature adults, and this has proven insufficient to describe differences among geographic isolates of tubificid oligochaetes serving as hosts for $M$. cerebralis (K. Beauchamp unpubl. obs.). Both field and laboratory exposures have demonstrated that certain populations classified as T. tubifex from the USA, Canada and Europe range from highly susceptible to completely resistant to infection by $M$. cerebralis (ElMatbouli et al. 1999b). Two recent studies on experimentally exposed T. tubifex have reported variable results on the release of the actinosporean stages of $M$. cerebralis, suggesting both a temporal and dose-re- sponse to parasite infection among different oligochaete populations (Gilbert \& Granath 2001, Stevens et al. 2001). Our previous phylogenetic studies using mitochondrial 16S rDNA (mt16S rDNA) markers identified 4 genetically distinct lineages of morphologically indistinguishable T. tubifex from North America; 3 of the lineages are also found in Europe (Beauchamp et al. 2001). In addition, we found that individuals from 1 mitochondrial lineage are resistant to infection from $M$. cerebralis. Therefore, understanding the genetic diversity and distribution of T. tubifex species that are susceptible or resistant to $M$. cerebralis is of immediate concern for the potential control of whirling disease.

The upper Colorado River represents a well-known and highly prized wild rainbow trout fisheries in the state of Colorado, USA Serious declines in this sport fishery have been thoroughly documented (Nehring \& Walker 1996, Nehring 1998, 1999, Thompson et al. 1999). The role of the Windy Gap Reservoir on the Colorado River is believed to be a major environmental factor contributing to the whirling disease that occurs among trout in the river below (Thompson \& Nehring 2000). A recent study by Zendt \& Bergerson (2000) examined the abundance and distribution of oligochaetes above, within and below the reservoir. However, what was not known, nor were the tools available for the assessment at that time, was the relative composition and genetics of susceptible and resistant Tubifex tubifex present in their samples. In this study we examined populations of aquatic oligochaetes for the prevalence of infection with Myxobolus cerebralis from the upper Colorado River, including Windy Gap Reservoir. We examined individual oligochaetes collected from each site to determine the prevalence of those releasing triactinomyxon stages of $M$. cerebralis. We then exposed those T. tubifex not found to be producing triactinomyxon stages, to spores of $M$. cerebralis obtained from infected trout to test their susceptibility as assessed 3 mo later by releases of triactinomyxons. We also applied recently developed molecular approaches to identify specific genotypes of $T$. tubifex that might be present in field samples and might correlate with the susceptibility or resistance of these oligochaetes to $M$. cerebralis infections.

\section{MATERIALS AND METHODS}

Sample collection and sorting. Two studies were carried out in 1998 and 1999. In the first study (1998), sediment samples were collected from the Windy Gap Reservoir (WG) and from several sites on the upper Colorado River (UCR, below Windy Gap Reservoir); samples from the UCR sites were combined for analysis. In the second study (1999), samples were collected 
from only 2 sites, WG and Breeze Bridge (BB, below Windy Gap Reservoir). In both studies, samples contained aquatic insects, mollusks, crustaceans and annelids. Using a dissecting microscope, oligochaetes were first grossly sorted based on the presence or absence of hair chaetae. At each collection site we observed 3 families of oligochaetes: Lumbriculidae, Naididae and 2 groups of Tubificidae (one species with and the other without hair chaetae).

In the first study, oligochaetes were collected on 21 September and 28 October 1998, and individual oligochaetes were distributed into multi-well plates with dechlorinated water and maintained for approximately $1 \mathrm{wk}$ at $15^{\circ} \mathrm{C}$ to determine if they were releasing actinosporean stages. Oligochaetes that did not release any actinosporeans were then placed in bulk culture according to the 4 groups mentioned above. The cultures were maintained in plastic containers (2 l) with $400 \mathrm{~g}$ sterilized sand and 11 dechlorinated tap water at $15^{\circ} \mathrm{C}$. The water was changed once per week and the oligochaetes were fed with Algamac-2000. The water from each container was examined weekly for the presence of actinosporeans. Approximately two-thirds of the water volume was passed through a $10 \mu \mathrm{m}$ Nitex screen. Actinosporeans trapped on the screen were concentrated into a volume of $50 \mathrm{ml}$ and viewed by phase-contrast microscopy as previously described (Markiw 1989, Andree et al. 1997). After 1 mo, individual oligochaetes were re-distributed into multi-well plates and screened for the presence of actinosporeans. In the second study, oligochaetes were collected on 13 September 1998 and sorted by the presence of hair chaetae (Tubifex tubifex). Only T. tubifex oligochaetes were transferred to bulk culture in the same manner as the first study.

Experimental exposures to Myxobolus cerebralis spores. For the first study, oligochaetes that did not release actinosporeans after 1 mo observation were exposed to freshly harvested $M$. cerebralis spores from infected rainbow trout $\left(5 \times 10^{2}\right.$ spores per oligochaete $)$ from the Mount Whitney hatchery, Independence, California, as previously described by El-Matbouli et al. (1999b). In the second study, only Tubifex tubifex were selected and separated for 2 experiments as follows: In Expt 1, oligochaetes were exposed on 12 October 1999 to $M$. cerebralis spores freshly harvested from rainbow trout (Mount Whitney, California) so that each oligochaete was exposed to $1.1 \times 10^{4}$ spores. In Expt 2, oligochaetes were exposed on 3 November 1999 to $M$. cerebralis spores obtained from brown trout (South Platte River, Colorado) and each oligochaete was exposed to $6 \times 10^{3}$ spores. Spores used in both studies were collected by the plankton centrifuge method (O'Grodnick 1975). After 3 mo, individual oligochaetes were plated and screened to determine which oligo- chaetes were releasing triactinomyxons (El-Matbouli et al. 1999b). At the end of the experiments (3 mo postexposure) oligochaetes releasing or not releasing triactinomyxons of $M$. cerebralis were fixed for genetic screening and morphological and molecular identification.

Genotype screening of Tubifex tubifex. Due to previous findings that natural populations of $T$. tubifex contain a mixture of morphologically indistinguishable genotypes, a PCR-based genetic screening method was developed. For each of the 3 major lineages found in T. tubifex from Colorado, a specific primer was designed for 1 strand and used in combination with a previously known reverse primer of one mt16S rDNA to yield a size-specific PCR product (present Fig. 1 and Beauchamp et al. 2001). The PCR cocktail contained 3 lineage-specific primers and the Tubifex-specific reverse primer $(1 \mu \mathrm{M}$ of each). For the genetic screening, genomic DNA was extracted using the QIAmp Tissue Kit (Qiagen) from up to 50 individual oligochaetes for each of the groups releasing or not releasing triactinomyxons of Myxobolus cerebralis. When there were less than 50 oligochaetes in a group, all oligochaetes were analyzed. In those cases in which none of the lineage-specific primers yielded a band or in which multiple bands were observed, the product of the PCR using the universal primers for mt16S rDNA was sequenced to determine the genotype (see next section).

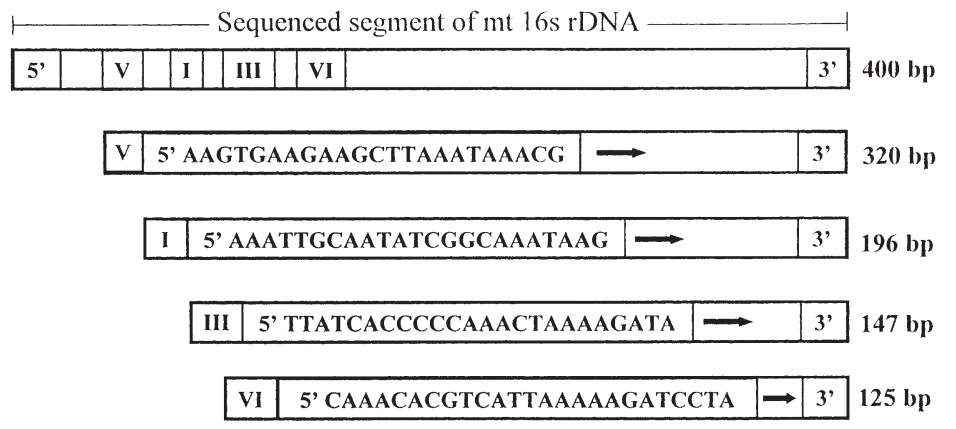

Fig. 1. Sequences and priming locations of 4 lineage specific primers within the $550 \mathrm{bp}$ segment of the mt16S rDNA yielding 1 lineage-specific amplification product with the Tubifexspecific primer on the complementary strand (Tub16R: 5' TAA RCC AAC ATY GAG GTG CCA 3'; Beauchamp et al. 2001). Top bar represents the entire segment of the mt16S rDNA amplified by the Tubifex spp.-specific primers and the priming sites of the 4 Lineage-Specific Primers I, III, V and VI (Sturmbauer et al. 1999, Beauchamp et al. 2001); lower bars represent lineage-specific amplification products and the orientation and sequence of each diagnostic primer. Only Lineage-Specific Primers I, III, and VI were used in this study. Size of each PCR-amplified product for each of the primers is shown on the right 
Morphological and molecular identification. The examined oligochaetes were cut in half. The anterior portion was fixed in $10 \%$ neutral buffered formalin and mounted in CMCP-10 high-viscosity mountant for morphological identification according to Kathman \& Brinkhurst (1998). The posterior of the oligochaete was used to extract genomic DNA by the same method described in the last section. For those oligochaetes that did not PCR-amplify with the lineage-specific primers, a 550 bp region of the mitochondrial $16 \mathrm{~S}$ gene (mt16S rDNA) was PCR-amplified using the universal primers 16sar and 16sbr (Palumbi et al. 1991). PCR products were directly sequenced from doublestranded DNA using the Sequenase Version 2 and an automated sequencer (ABI 377). Both strands were sequenced. Additional sequences of Tubifex tubifex used in the analysis were from Sturmbauer et al. (1999) and Beauchamp et al. (2001).

DNA sequences and phylogenetic reconstructions. Sequences were aligned with the aid of the computer program MacDNASIS Version 3.7 (Hitachi Software Engineering America) and Clustal V (Higgins \& Sharp 1989). Phylogenetic relationships were assessed by maximum-parsimony (MP), using the heuristic search and the neighbor-joining (NJ) methods as implemented by the software package PAUP (Version 4.0; Swofford 1998) with 1000 bootstrap replicates (Felsenstein 1985, Hedges 1992).

Statistical analyses. All statistical analyses were performed using the software program SAS Version 8.1 (SAS Institute). Tests of proportions of the prevalence and susceptibility of oligochaetes and the genetic screening comparisons between all sites, dates or lineages employed Fisher's exact test of independence (Christensen 1990). We used Fisher's exact test throughout our study rather than the more common chi-square comparison because, at times, sample sizes were too small for the chi-square analysis (see SAS Version 8.1).

\section{RESULTS}

\section{Prevalence of infection}

In the first study, initial screening of the 4 groups of oligochaetes from both sites and at both collection times demonstrated that only Tubificidae with hair chaetae (Tubifex tubifex) were found releasing triactinomyxon stages of Myxobolus cerebralis. Throughout the studies, no T. tubifex were found releasing any actinosporeans other than those characteristic of $M$. cerebralis. Combining data from both collection times, the number of infected T. tubifex was 38 from a total of 4349 oligochaetes from the WG site and 22 from a total of 3376 from the UCR site (Table 1). The prevalence of T. tubifex releasing triactinomyxons from naturally acquired infections ranged from 0.4 to $1.4 \%(0.7 \%$ combined) at WG and 0.4 to $0.8 \%$ at UCR $(1.0 \%$ combined).

Susceptibility of the Tubifex tubifex not initially releasing triactinomyxons stages was assessed in the laboratory following exposure to spores of Myxobolus cerebralis. There were $230 \mathrm{~T}$. tubifex from a total of 3532 from the WG site and 181 from a total of 1789 from the UCR site found releasing triactinomyxons at 3 mo post exposure (Table 1). The prevalence of infection therefore ranged from 5.3 to $8.5 \%(6.5 \%$ combined) at WG and 4.2 to $14.1 \%$ (10.1\% combined) at UCR in 1998. There was no significant difference in susceptibility of oligochaetes between the WG and UCR sites $(p=0.8107)$ or between the collection dates 13 September $(p=0.3168)$ and 12 October $(p=0.1617)$ in 1999. However, there were more susceptible oligochaetes on the first collection date (13 September) within each site, (WG: $p=0.0012$; UCR: $p=0.0020$ ) compared to the other collection dates.

In the second study, all Tubifex tubifex collected were exposed to Myxobolus cerebralis spores from 2 sources, brown trout from the South Platter River and rainbow trout from Mount Whitney, immediately upon return to the laboratory. Therefore, no information on the initial prevalence of infection in the oligochaetes was obtained. Also in contrast to the first study, oligochaetes were examined with newly developed genetic markers at the termination of the study. The number of oligochaetes releasing triactinomyxons

Table 1. Tubifex tubifex. Prevalence of Myxobolus cerebralis infection among Colorado River oligochaetes in Study 1 (1998). The prevalence of infection among oligochaetes from the field was determined as the percentage releasing triactinomyxons out of the total collected. Susceptibility of the oligochaetes from the field not found releasing triactinomyxons was assessed 3 mo after exposure to $M$. cerebralis spores in the laboratory. Sites of oligochaete collections were Windy

Gap Reservoir (WG) and Upper Colorado River (UCR)

\begin{tabular}{|lcccc|}
\hline \multirow{2}{*}{ Experiment } & \multicolumn{4}{c|}{ Collection site } \\
& \multicolumn{2}{c|}{ WG } & UCR \\
& 21Sep & 28Oct & 21Sep & 28Oct \\
\hline Field experiment & & & & \\
Total oligochaetes collected & 2075 & 3312 & 2699 & 2078 \\
Number of T. tubifex & 1929 & 2420 & 2522 & 854 \\
Number initially infected & 29 & 9 & 19 & 3 \\
Prevalence (\%) & 1.5 & 0.4 & 0.8 & 0.4 \\
Laboratory experiment & & & & \\
Number exposed & 1362 & 2170 & 1069 & 720 \\
Laboratory infected & 116 & 114 & 151 & 30 \\
Susceptibility (\%) & 10.4 & 5.6 & 15.6 & 4.6 \\
Prevalence (\%) & 8.5 & 5.3 & 14.1 & 4.2 \\
\hline
\end{tabular}


Table 2. Tubifex tubifex from Expts 1 and 2 of Study 2 (1999) found releasing (positive) or not releasing (negative) triactinomyxons 3 mo following experimental exposure to spores of Myxobolus cerebralis. The number of dead oligochaetes represents the difference between the number of oligochaetes initially exposed and the number remaining 3 mo post-exposure. Oligochaetes were collected from Windy Gap Reservoir (WG) and Breeze Bridge (BB), Colorado, and exposed to $M$. cerebralis spores harvested from rainbow trout at Mount Whitney, California (Expt 1), or from brown trout at South Platte River,Colorado (Expt 2)

\begin{tabular}{|lcccc|}
\hline & \multicolumn{2}{c}{ Expt 1 } & \multicolumn{2}{c|}{ Expt 2 } \\
\hline Date of collection & \multicolumn{2}{c}{ 13 Sep } & \multicolumn{2}{c}{ 13 Sep } \\
Date of exposure & \multicolumn{2}{c}{ 12 Oct } & Nov \\
Oligochaete collection & WG & BB & WG & BB \\
site & & & & \\
Number exposed & $295^{\mathrm{a}}$ & $288^{\mathrm{a}}$ & $245^{\mathrm{b}}$ & $264^{\mathrm{b}}$ \\
Number positive & 21 & 9 & 24 & 12 \\
Number negative & 24 & 208 & 199 & 166 \\
Number dead & 250 & 71 & 22 & 86 \\
a Each oligochaete exposed to $1.1 \times 10^{4}$ spores & \\
b Each oligochaete exposed to $6 \times 10^{3}$ spores \\
\hline
\end{tabular}

(susceptible) ranged from 9 to 21 in Expt 1 with spores originating from Mount Whitney and 12 to 24 in Expt 2 with spores from the South Platte River origin (Table 2). The number of oligochaetes not releasing triactinomyxons (resistant) ranged from 24 to 208 in both experiments. There was no significant difference in the proportion of susceptible or resistant oligochaetes between Expts 1 and 2 at either site $(p=0.3531)$. The greater mortality of oligochaetes from WG in Expt 1 was unexplained. To reduce stress on the oligochaetes, they were only counted at the onset and termination (3 mo) of the experiments, and this precluded determining the susceptibility or genotype of oligochaetes dying during the experimental period. There was a difference in the susceptibility of oligochaetes between the 2 sites in Expt 1 and for the 2 experiments combined (both $\mathrm{p}<0.0001$ ), but not between the WG and BB sites in Expt $2(p=0.2180)$. The mortality in Expt 2 was $0.09 \%$ (22 of 245) among WG oligochaetes and $0.326 \%$ (86 of 264) among those from BB, i.e. they were significantly different from each other $(p<0.0001)$.

\section{Genetic screening}

The genetic screening assay based on the mt16S lineage-specific PCR separated each mitochondrial lineage by the size of the resulting amplified fragment. Individual oligochaetes representing the 3 lineages (I, III, VI) yield a single PCR product of defined length (Fig. 2). Those oligochaetes from which no amplified fragment was observed using the lineage-specific primers, and whose DNA sequence was determined

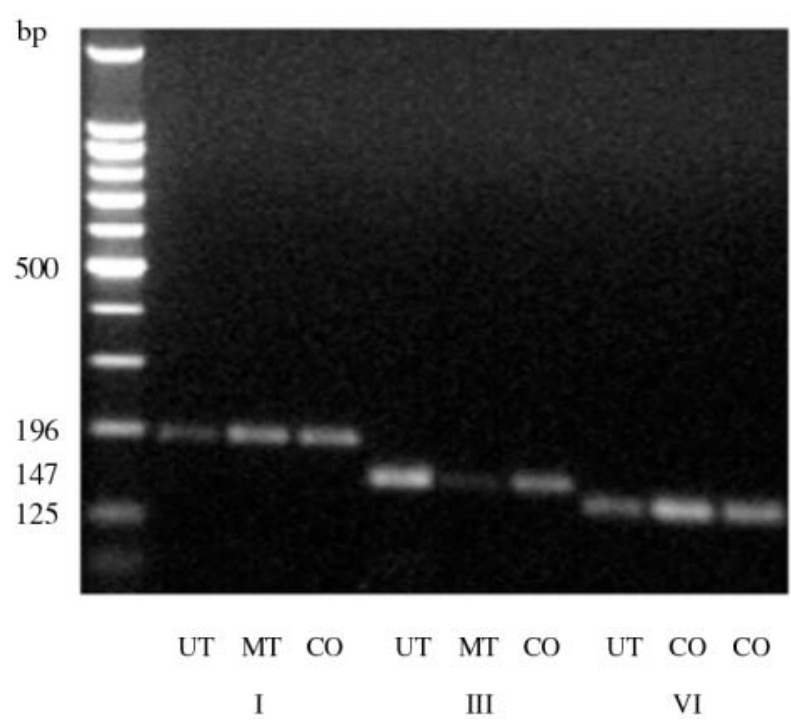

Fig. 2. Tubifex tubifex. Agarose gel electrophoresis of PCRamplified genomic DNA using mt 16S rDNA Lineage-Specific Primers I (196 bp), III (147 bp) and VI (125 bp) of oligochaetes from Logan River, Utah (UT), Bozeman Fish Tech Center, Montana (MT) and Windy Gap Reservoir, Colorado (CO). A DNA size standard ladder (100 bp) is shown on the left side of the gel $(2 \%)$

using the 16sar and 16sbr primer, all belonged to Lineage V (GenBank Accession No. AF426845AF426860), with the exception of 1 WG oligochaete from Lineage III (AF426844: Fig. 3). The analysis of samples from WG revealed that susceptible and resistant oligochaetes were found in Lineages I and III in different proportions (Table 3). At WG, Lineage III was more likely to have resistant oligochaetes than lineage I $(p=0.0360)$. In contrast to WG reservoir, BB was more likely to have resistant oligochaetes in Lineage $\mathrm{V}$ than III ( $p=0.0063)$. At BB, the only lineage with susceptible oligochaetes was III; no susceptible oligochaetes were observed in Lineages I ( $\mathrm{n}=12), \mathrm{V}(\mathrm{n}=21)$ and VI $(\mathrm{n}=6)$. Interestingly, oligochaetes in lineage $\mathrm{V}$ were resistant and only found at $\mathrm{BB}$. The lowest number of oligochaetes was found in lineage VI at both sites, and they were all resistant. There was no evidence of Lineages II and IV (Sturmbauer et al. 1999) in our study.

\section{DISCUSSION}

In this study over 10164 oligochaetes were examined and only Tubifex tubifex was found to be susceptible to Myxobolus cerebralis infections, as demonstrated by the release of the triactinomyxons stages following either natural or experimental exposure to the parasite. These findings are in agreement with previous studies that report $T$. tubifex as the sole host for 
M. cerebralis (Markiw \& Wolf 1983, Wolf \& Markiw 1984, Markiw 1986, Wolf et al. 1986, El-Matbouli \& Hoffman 1989, 1995, 1998). Our results do not support the proposal by Brinkhurst (1996) that there may be other alternate oligochaete hosts for $M$. cerebralis in the families Lumbriculidae, Naididae and other Tubificidae. Our daily screening of individual oligochaetes never revealed releases of more than 1 morphological type of actinosporean. This suggests that in our study sites T. tubifex is supporting few other myxosporean infections. In contrast, Yokoyama et al. (1991) found several types of actinosporeans released from a single T. tubifex obtained from a fish pond in Japan.

The susceptibility of Tubifex tubifex at our study sites in the upper Colorado River ranged from 0.4 to $1.5 \%$; This is very similar to the 1 to $2.0 \%$ previously

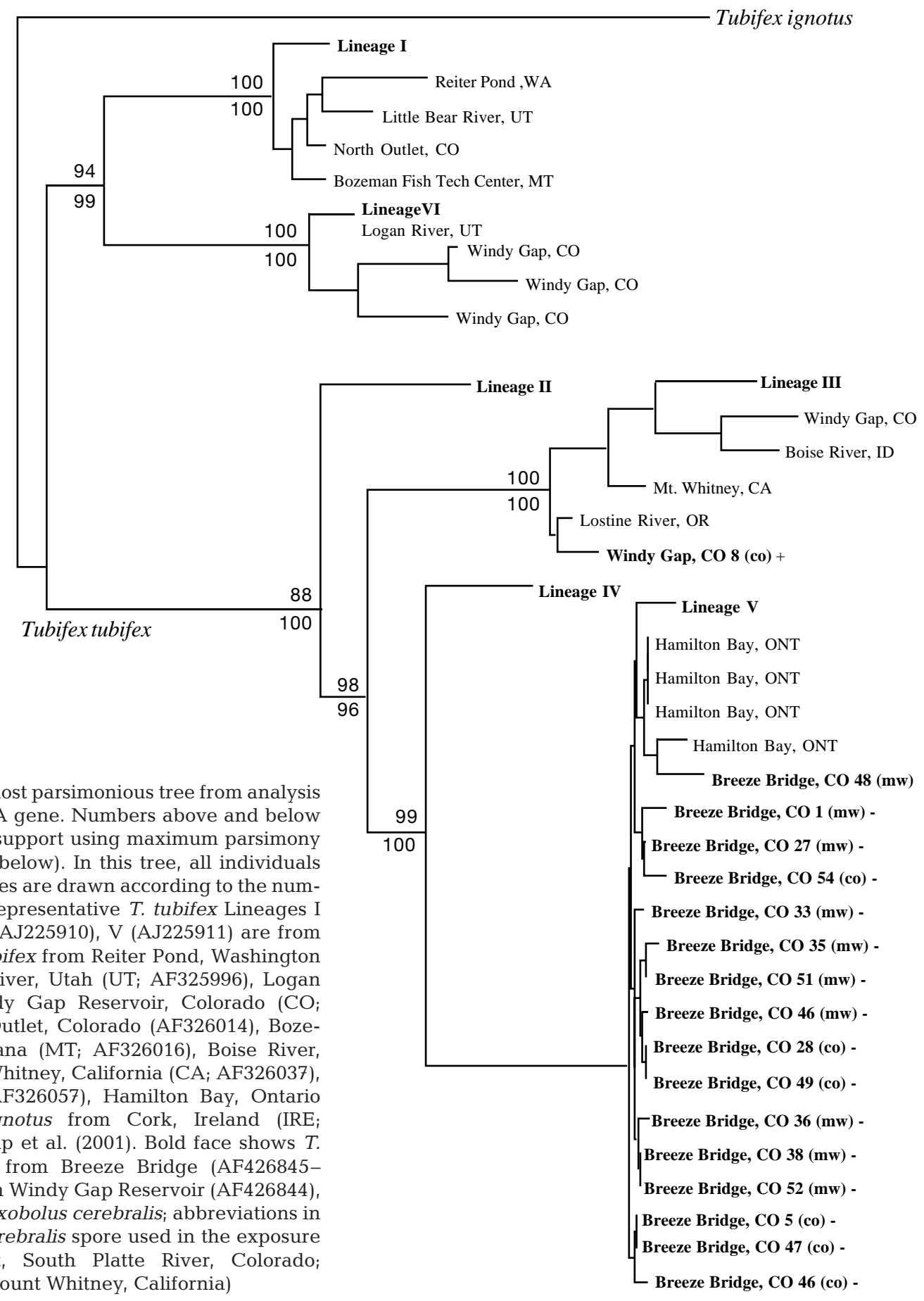

Fig. 3. Tubifex tubifex. Single most parsimonious tree from analysis of a portion of the mt $16 \mathrm{~S}$ rDNA gene. Numbers above and below the nodes represent bootstrap support using maximum parsimony (above) and neighbor joining (below). In this tree, all individuals are represented and the branches are drawn according to the number of inferred substitutions. Representative $T$. tubifex Lineages I (AJ225906), II (AJ225907), IV (AJ225910), V (AJ225911) are from Sturmbauer et al. (1999). T. tubifex from Reiter Pond, Washington (WA; AF325998), Little Bear River, Utah (UT; AF325996), Logan River, Utah (AF325991), Windy Gap Reservoir, Colorado (CO; AF326006-AF326009), North Outlet, Colorado (AF326014), Bozeman Fish Tech Center, Montana (MT; AF326016), Boise River, Idaho (ID; AF326004), Mount Whitney, California (CA; AF326037), Lostine River, Oregon (OR; AF326057), Hamilton Bay, Ontario (ONT; AF326025) and T. ignotus from Cork, Ireland (IRE, AF325987) are from Beauchamp et al. (2001). Bold face shows $T$. tubifex that are negative (-) from Breeze Bridge (AF426845AF426860) and positive (+) from Windy Gap Reservoir (AF426844), Colorado, after exposure to Myxobolus cerebralis; abbreviations in parentheses: locations of $M$. cerebralis spore used in the exposure experiment (co: brown trout, South Platte River, Colorado; mw: rainbow trout, Mount Whitney, California) 
Table 3. Tubifex tubifex. Distribution into four 16S mtDNA lineages of oligochaetes releasing (+) and not releasing (-) triactinomyxons of Myxobolus cerebralis in Study 2 from genetically heterogeneous populations collected from Windy Gap Reservoir (WG) and Breeze Bridge (BB), Colorado (see Table 2), and numbers in geographic populations for Lineages I, III, V and VI (see Fig. 2). T. tubifex were exposed to spores from rainbow trout (Mount Whitney, California) and brown trout (South Platte River, Colorado) in Expts 1 and 2, respectively

\begin{tabular}{|lccccccccccccc|}
\hline \multirow{2}{*}{ Lineage } & \multicolumn{3}{c}{ Expt 1 } & \multicolumn{4}{c}{ Expt 2 } & \multicolumn{4}{c|}{ Combined results } \\
& \multicolumn{2}{c}{ WG } & \multicolumn{2}{c}{ BB } & \multicolumn{2}{c|}{ WG } & \multicolumn{3}{c|}{ BB } & \multicolumn{2}{c}{ WG } & \multicolumn{2}{c}{ BB } \\
& $(+)$ & $(-)$ & $(+)$ & $(-)$ & $(+)$ & $(-)$ & $(+)$ & $(-)$ & $(+)$ & $(-)$ & $(+)$ & $(-)$ \\
\hline I & 1 & 17 & 0 & 7 & 23 & 7 & 0 & 5 & 24 & 24 & 0 & 12 \\
III & 20 & 5 & 9 & 35 & 1 & 43 & 12 & 28 & 21 & 48 & 21 & 63 \\
V & 0 & 0 & 0 & 10 & 0 & 0 & 0 & 11 & 0 & 0 & 0 & 21 \\
VI & 0 & 1 & 0 & 1 & 0 & 0 & 0 & 5 & 0 & 1 & 0 & 6 \\
\hline
\end{tabular}

our study, 2 (V, VI) appear to be resistant to infection with Myxobolus cerebralis, while the other 2 (I, III) appear to contain both susceptible and resistant oligochaetes. There was no evidence at our study sites for the 2 lineages of $T$. tubifex described by Sturmbauer et al. (1999) that are known from freshwater habitats in Europe.

One lineage of Tubifex tubifex (V) found in our study at the Breeze Bridge site is related to oligochaetes from Hamilton Bay, Ontario, Canada, that have been shown to be resistant to Myxobolus cerebralis infections in the laboratory. The Hamilton Bay oligoreported for wild populations of $T$. tubifex and other oligochaetes infected with myxosporeans (Markiw 1986, Burtle et al. 1991, Yokoyama et al. 1991, 1993, Styer et al. 1991, Kent et al. 1993, El-Matbouli \& Hoffman 1995, Xiao \& Desser 1998). Rather than assessing prevalence by releases of actinosporeans, Rognlie \& Knapp (1998) and Zendt \& Bergerson (2000) obtained similar prevalence estimates (0.8 to $2.6 \%$ ) using PCR to detect $M$. cerebralis infections among wild T. tubifex collected from enzootic areas of whirling disease in the states of Montana and Colorado. Our experimental exposures of $T$. tubifex, either after holding them in laboratory or immediately after collection, clearly showed that there is a much larger proportion of the population (up to $14 \%$ ) that is susceptible to $M$. cerebralis infections, and this may differ between study sites (Tables 1 and 2). Several factors potentially influence the susceptibility of $T$. tubifex to $M$. cerebralis infections. They may include a number of environmental factors such as water quality and temperature (ElMatbouli et al. 1999b), season, day-length, etc. (Yokoyama et al. 1991, Rognlie \& Knapp 1998, Xiao \& Desser 1998). The dose and perhaps age of spores that the oligochaetes ingest are also critical (Stevens et al. 2001). In contrast, spore origin appeared not to greatly influence the susceptibility of $T$. tubifex to spores originating from 2 host fish species (rainbow and brown trout) and geographic sites (California and Colorado) in our study. Studies characterizing the genotype and virulence of strains of $M$. cerebralis suggest they comprise a fairly homogeneous group, regardless of geographic origin (Andree et al. 1997, T. McDowell et al. unpubl. data). Host factors, such as size, age and genotype of the oligochaete, are also presumed to greatly influence the susceptibility to $M$. cerebralis infections.

Our initial molecular screening of Tubifex tubifex in the upper Colorado River suggest that it is not a homogeneous taxon but consists instead of several genetically distinct lineages. Of the 4 lineages of $T$. tubifex found in chaetes have been shown to be capable of ingesting and then inactivating the spores of $M$. cerebralis (M. El-Matbouli unpubl. data). The spores ingested by these oligochaetes hatch in the intestine but cannot complete the infection cycle; thus the oligochaetes effectively remove the spores they consume from the environment. These oligochaetes essentially act as biological filters, preventing susceptible oligochaetes from coming into contact with the parasite, a phenomenon demonstrated by laboratory trials examining experimental infections of mixed populations of susceptible and resistant Tubifex spp. (M. El-Matbouli unpubl. data). The relative abundance of Tubifex species that are completely or partially resistant to $M$. cerebralis infections could therefore exert considerable influence on the infectivity and therefore the impact of whirling disease on wild or captive populations of trout. Other important features of infections once they become established in the oligochaete host, including duration and patterns of release of triactinomyxons, may influence the severity of whirling disease in a given watershed (Gilbert \& Granath 2001, Stevens et al. 2001).

The ecology of the habitat throughout a species range may also influence host-parasite interactions among populations of Tubifex spp. Certain waters in the state of Colorado have been characterized as highly impacted by whirling disease, based upon the severity of infections in wild and sentinel trout and high numbers of triactinomyxons of Myxobolus cerebralis found in the water by periodic filtration (Nehring 1998, 1999, Thompson et al. 1999, Thompson \& Nehring 2000, Nehring \& Thompson 2001). The upper Colorado River, downstream from Windy Gap Reservoir, is one such highly impacted site. The dam creating the reservoir is presumed to have established a new habitat conducive to the greater abundance of oligochaetes susceptible to M. cerebralis (Zendt \& Bergersen 2000). Water flow, temperature and dissolved gases have also 
been studied in relation to the severity of whirling disease at this site (Schisler et al. 2000). Together, these data suggest that Windy Gap Reservoir represents a significant point source of infection for wild trout in the upper Colorado River. Our studies of the oligochaete populations in this area suggest that particular lineages (e.g. I and III) that contain oligochaetes susceptible to $M$. cerebralis are abundant and may in part be responsible for the severity of whirling disease at this site. Of interest however, is the presence at BB of oligochaetes from lineages that may represent more resistant oligochaetes (e.g. V and VI), whose abundance, if increased, might dampen the overall impact of whirling disease in the upper Colorado River.

Our data supports the hypothesis that the abundance and genotype of Tubifex tubifex are important in defining high- and low-impact areas in the upper Colorado River. More in-depth genetic characterizations of T. tubifex acting as hosts for Myxobolus cerebralis are underway with the ultimate goal of determining how the abundance and distribution of these naturally occurring oligochaete populations influence the severity of whirling disease in wild trout populations.

Acknowledgements. This work was supported in part by the US Fish and Wildlife Service, Trout Unlimited, Whirling Disease Foundation, National Fish and Wildlife Foundation. We are grateful to K. Andree, G. Bernardi and J. Corbin for help with molecular methods and analyses. We thank T. Carpenter, M. Georgiadis, and M. Whatnik for help on the statistics. We would like to acknowledge T. McDowell and K. Mukkatira for their efforts in maintaining oligochaetes and fish cultures and to researchers for technical support and collection of oligochaetes. We appreciate the assistance of the Colorado Division of Wildlife and their personnel for collection of field materials. K. Andree, G. Bernardi, and K. Thompson provided helpful comments on earlier versions of the manuscript.

\section{LITERATURE CITED}

Andree KA, Gresoviac SJ, Hedrick RP (1997) Small subunit ribosomal RNA sequences unite alternate actinosporean stages and myxosporean stages of Myxobolus cerebralis the causative agent of whirling disease in salmonid fish. J Eukaryot Microbiol 44:208-215

Andree KA, El-Matbouli M, Hoffman RW, Hedrick RP (1999) Comparisons of $18 \mathrm{~S}$ and ITS-1 rDNA sequences of selected geographic isolates of Myxobolus cerebralis. Int J Parasitol 29:771-775

Beauchamp KA, Kathman RD, McDowell TS, Hedrick RP (2001) Molecular phylogeny of tubificid oligochaetes with special emphasis on Tubifex tubifex (Tubificidae). Mol Phylogenet Evol 19:216-224

Brinkhurst RO (1996) On the role of tubificid oligochaetes in relation to fish disease with special reference to the Myxozoa. Annu Rev Fish Dis 6:29-40

Burtle GJ, Harrison LR, Styer EL (1991) Detection of a triactinomyxid myxozoan in an oligochaete from ponds with proliferative gill disease in channel catfish. J Aquat Anim Health 3:281-287
Christensen R (1990) Log-linear models, 1st edn. SpringerVerlag, New York, p 56

Day KE, Kirby S, Reynoldson TB (1995) The effect of manipulation of freshwater sediments on responses of benthic invertebrates in whole-sediment toxicity tests. Environ Toxicol Chem 14:1333-1343

El-Matbouli M, Hoffman RW (1989) Experimental transmission of two Myxobolus spp. developing bisporogeny via tubificid oligochaetes. Parasitol Res 75:461-464

El-Matbouli M, Hoffman RW (1995) Light and electron microscopic observations on the route of the triactinomyxonssporoplasm of Myxobolus cerebralis from epidermis into rainbow trout cartilage. J Fish Biol 46:919-935

El-Matbouli M, Hoffman RW (1998) Light and electron microscopic studies on the chronological development of Myxobolus cerebralis to the actinosporean stage in Tubifex tubifex. Int J Parasitol 28:195-217

El-Matbouli M, Hoffman RW, Schoel H, McDowell TS, Hedrick RP (1999a) Whirling disease: host specificity and interaction between the actinosporean stage of Myxobolus cerebralis and rainbow trout Oncorhynchus mykiss. Dis Aquat Org 35:1-12

El-Matbouli M, McDowell TS, Antonio DB, Andree KB, Hedrick RP (1999b) Effect of water temperature on the development, release, and survival of the triactinomyxon. Int J Parasitol 29:627-641

Felsenstein J (1985) Confidence limits on phylogenies: an approach using the bootstrap. Evolution 39:783-791

Gilbert MA, Granath WO Jr (2001) Persistent infection of Myxobolus cerebralis, the causative agent of salmonid whirling disease, in Tubifex tubifex. J Parasitol 87:101-107

Hedges SB (1992) The number of bootstrap replications needed for accurate estimation of the bootstrap P value in phylogenetic studies. Mol Biol Evol 9:366-369

Hedrick RP (1998) Relationships of the host, pathogen and environment: implications for diseases of cultured and wild fish populations. J Aquat Anim Health 10:107-111

Hedrick RP, El-Matbouli M, Adkison MA, MacConnell E (1998) Whirling disease: re-emergence among wild trout. Immunol Rev 162:365-376

Hedrick RP, McDowell TS, Gay M, Marty GD, Georgiadis MP, MacConnell E (1999a) Comparative susceptibility of rainbow trout Oncorhynchus mykiss and brown trout Salmo trutta to Myxobolus cerebralis the cause of salmonid whirling disease. Dis Aquat Org 37:173-183

Hedrick RP, McDowell TS, Mukkatira K, Georgiadis MP, MacConnell E (1999b) Susceptibility of selected inland salmonids to experimentally induced infections with Myxobolus cerebralis, the causative agent of whirling disease. J Aquat Anim Health 11:330-439

Higgins DG, Sharp PM (1989) Fast and sensitive multiple sequence alignments on a microcomputer. CABIOS 5:151-153

Kathman RD, Brinkhurst RO (1998) Guide to the freshwater oligochaetes of North America. Aquatic Resources Center, College Grove, TN

Kent ML, Whitaker DJ, Margolis L (1993) Transmission of Myxobolus arcticus Pugachev and Khokhlov, 1979, a myxosporean parasite of Pacific salmon, via a triactinomyxon from the aquatic oligochaete Stylodrilus heringianus (Lumbriculidae). Can J Zool 71:1207-1211

Kent ML, Margolis L, Corliss JO (1994) The demise of a class of protists: taxonomic and nomenclatural revisions proposed for the protist phylum Myxozoa Grasse, 1970. Can J Zool 72:932-937

Markiw ME (1986) Salmonid whirling disease: dynamics of experimental production of the infective stage - the triactinomyxon spore. Can J Fish Aquat Sci 43:521-526 
Markiw ME (1989) Salmonid whirling disease: myxosporean and actinosporean stages cross-react in direct fluorescent antibody test. J Fish Dis 12:137-141

Markiw ME, Wolf K (1983) Myxosoma cerebralis (Myxozoa: Myxosporea) etiologic agent of salmonid whirling disease requires tubificid oligochaetes (Annelida: Oligochaetes) in its life cycle. J Protozool 30:561-564

Nehring RB (1998) Stream fisheries investigations (Final Report, Federal Aid Project F-237-R5). Colorado Division of Wildlife, Fort Collins, CO

Nehring RB (1999) Stream fisheries investigations (Progress Report, Federal Aid Project F-237-R5). Colorado Division of Wildlife, Fort Collins, CO

Nehring RB, Thompson KG (2001) Impact assessment of some physical and biological factors in the whirling disease epizootic among wild trout in Colorado (Special Report No. 76). Colorado Division of Wildlife, Fort Collins, CO

Nehring RB, Walker PG (1996) Whirling disease in the wild: the new reality in the intermountain west. Fisheries (Bethesda) 21:28-30

Nickum D (1999) Whirling disease in the United States: a summary of progress in research and management. Trout Unlimited's Coldwater Conservation Fund, Boulder, CO

O'Grodnick J (1975) Whirling disease Myxosoma cerebralis spore concentration using the continuous plankton centrifuge. J Wildl Dis 11:54-57

O'Grodnick J (1978) Susceptibility study of various salmonids in whirling disease: histological staining and spore concentration procedures. Mar Fish Rev 40:30-31

O'Grodnick J (1979) Susceptibility of various salmonids to whirling disease (Myxosoma cerebralis). Trans Am Fish Soc 108:187-190

Palumbi SR, Martin A, Romano S, McMillan WO, Stice L, Grabowski G (1991) The simple fool's guide to PCR, Version 2. University of Hawaii, Zoology Department, Honolulu, HI

Rognlie MC, Knapp SE (1998) Myxobolus cerebralis in Tubifex tubifex from a whirling disease epizootic in Montana. J Parasitol 84:711-713

Schisler GJ, Bergersen EP, Walker PG (2000) Effects of multiple stressors on morbidity and mortality of fingerling rainbow trout infected with Myxobolus cerebralis. Trans Am Fish Soc 129:859-865

Stevens R, Kerans BL, Lemmon JC, Rasmussen C (2001) The effects of Myxobolus cerebralis myxospore dose on triactinomyxon production and biology of Tubifex tubifex

Editorial responsibility: Wolfgang Körting (Contributing Editor), Hannover, Germany from two geographic regions. J Parasitol 87:315-321

Sturmbauer C, Opadiya GB, Niederstätter H, Riedmann A, Dallinger R (1999) Mitochondrial DNA reveals cryptic oligochaete species differing in cadmium resistance. Mol Biol Evol 16:967-974

Styer, EL, Harrison LR, Burtle GJ (1991) Experimental production of proliferative gill disease in channel catfish exposed to a myxozoan-infected oligochaete, Dero digitata. J Aquat Anim Health 3:288-291

Swofford DL (1998) PAUP* (Version 4) Phylogenetic analysis using parsimony ( ${ }^{*}$ and other methods). Sinauer Associates, Sunderland, MA

Thompson KG, Nehring RB (2000) A simple technique used to filter and quantify the actinospores of Myxobolus cerebralis and determine its seasonal abundance in the Colorado River. J Aquat Anim Health 12:316-323

Thompson KG, Nehring RB, Bowden DC, Wygant T (1999) Field exposure of seven species or subspecies of salmonids to Myxobolus cerebralis in the Colorado River, Middle Park, Colorado. J Aquat Anim Health 11:312-329

Vincent ER (1996) Whirling disease and wild trout: the Montana experience. Fisheries (Bethesda) 21:32-34

Wolf K, Markiw ME (1984) Biology contravenes taxonomy in the Myxozoa: new discoveries show alternation of invertebrate and vertebrate hosts. Science 225:1449-1452

Wolf K, Markiw ME, Hiltunen JK (1986) Salmonid whirling disease: Tubifex tubifex (Muller) identified as the essential oligochaete in the protozoan life cycle. J Fish Dis 9:83-85

Xiao C, Desser SS (1998) Actinosporean stages of myxozoan parasites of oligochaetes from Lake Sasajewun, Algonquin Park, Ontario: new forms of echinactinomyxon, neoactinomyxon, aurantiactinomyxon, guyenotia, synactinomyxon and antonactinomyxon. J Parasitol 84:1010-1019

Yokoyama H, Ogawa K, Wakabayashi H (1991) A new collection method of actinosporeans-a probable infective stage of myxosporeans of fishes-from tubificids and experimental infection of goldfish with the actinosporean, Raabeia sp. Fish Pathol 26:133-138

Yokoyama H, Ogawa K, Wakabayashi H (1993) Some biological characteristics of actinosporeans from the oligochaete Branchiura sowerbyi. Dis Aquat Org 17:223-228

Zendt JS, Bergerson EP (2000) Distribution and abundance of the aquatic oligochaete host Tubifex tubifex for the salmonid whirling disease parasite Myxobolus cerebralis in the upper Colorado River Basin. N Am J Fish Manag 20: $502-512$

Submitted: October 22, 2001; Accepted: February 1, 2002

Proofs received from author(s): July 26, 2002 